TTR

Traduction, terminologie, re?daction

\title{
Translation from, to and within the Atlantic Creoles
}

\section{George Lang}

Volume 13, numéro 2, 2e semestre 2000

Les Antilles en traduction

The Caribbean in Translation

URI : https://id.erudit.org/iderudit/037409ar

DOI : https://doi.org/10.7202/037409ar

Aller au sommaire du numéro

\section{Éditeur(s)}

Association canadienne de traductologie

ISSN

0835-8443 (imprimé)

1708-2188 (numérique)

Découvrir la revue

Citer cet article

Lang, G. (2000). Translation from, to and within the Atlantic Creoles. TTR, 13(2), 11-28. https://doi.org/10.7202/037409ar

\section{Résumé de l'article}

Traduction et créoles atlantiques - La traduction des langues créoles est sujette aux désavantages que ces langues elles-mêmes rencontrent : de bas niveaux d'alphabétisation, le manque d'orthographes établies, les effets néfastes du pouvoir que les langues « métropolitaines » exercent sur elles. Les difficultés générales de la traduction littéraire se trouvent donc aggravées quand il s'agit de la traduction soit d'une langue créole, soit vers une langue créole, soit entre des langues créoles, et les conditions sociologiques de base affectent l'entreprise de traduction différemment si le créole est source ou cible ou encore si des créoles servent les deux fonctions à la fois - bien que ce dernier cas soit effectivement rare. Cette étude de ces trois modes de traduction créole reposera sur plusieurs points reconnus de la traductologie, en particulier le rôle que joue l'implicature dans la traduction des langues dont les cultures sont apparentées (Venuti, 1997). Inversement, celui-là et d'autres concepts traductologiques exposés par Robinson (1997) pourraient s'avérer utiles aux créolistes qui se penchent sur les problèmes sociaux et politiques qui frappent ces langues.
Tous droits réservés @ TTR: traduction, terminologie, rédaction - Les auteurs, 2000
Cect protégé par la loi sur le droit d'auteur. L'utilisation des services d'Érudit (y compris la reproduction) est assujettie à sa politique d'utilisation que vous pouvez consulter en ligne.

https://apropos.erudit.org/fr/usagers/politique-dutilisation/ 


\section{Translation from, to and within the Atlantic Creoles}

\section{George Lang}

\section{Introduction}

Translation involving creole languages suffers the general disadvantage of writing in creoles: low levels of literacy, the lack of standard orthographies, the overwhelming prestige, both economic and cultural, of the metropolitan languages with which they compete. The pitfalls attendant to translation in any language are thus aggravated when translating to and from creoles, and these adverse sociolinguistic conditions affect the role of creoles as source and as target languages differently, insuring, for example, that creoles are much more frequently SLs than TLs, a slight anomaly in the world-wide pattern in which "developing languages" are usually TLs, English being the most likely SL (Venuti, 1997, p. 160; Robinson, 1997, pp. 234-235). Another possibility is of course that creoles serve as both SL and TL, and that translation be between or among creoles -- a rather rare case. This third eventuality raises several issues of translation theory, in particular the role of shared implicature in languages whose cultures are related. In the case of translation, implicature has been defined as "a feature of the foreign text that reveals a difference between the foreign [SL] and domestic [TL] cultures, usually a gap in the domestic reader's knowledge for which the translator must somehow compensate" (Venuti, 1997, p. 21). Yet as those who have control of more than one Romance language know, the information necessitating compensation is sometimes shared in cognate languages, the implications of Italian idioms al pane pane ed al vino vino overlapping with those of Spanish al pan pan y al vino vino, to cite only one example among thousands. Similar overlap occurs among creole languages, even those of different 
lexical bases, such as Surinamese Sranan, whose vocabulary is Englishbased, and Haitian Kreyol, which is French-based, discussed in the final section below ${ }^{1}$.

The nature of this common creole culture, which "substratists" often attribute to the African diasporan origins of the Atlantic creoles, is worthy of more commentary than space permits here, where the focus must fall on the three different translational situations involving creoles: 1) creoles to metropolitan languages (creoles as SLs); 2) metropolitan to creoles (creoles as TLs); and 3) creoles to creoles (as both SLs and TLs) ${ }^{2}$. I shall return on several occasions to the question of implicature, a tool with which to understand the commonality of creoles - the conundrum at the heart of creole linguistics - as well as the forms of interference which hold between creoles and their counterpart "metropolitan" languages.

\section{Creoles to metropolitan languages (creoles as SLs)}

In this context, $I$ use "metropolitan" to avoid a set of circumlocutions which typically plagues creolists. There is no single satisfactory term for the prestigious European languages from which is drawn most of the vocabulary of the Atlantic creoles spoken in West Africa, including the Cape Verde islands, and in the Caribbean, including the culturally Caribbean continental shelf surrounding the basin itself. If creoles are defined as "vernacular" one might call these other languages "vehiculars," but it is not always the case that vehiculars are not vernacular, and the distinction vernacular/vehicular is not widely accepted due to its innate relativity. Creoles are often defined and classified in terms of their "lexical base", but apart from the fact that this designation makes for clumsy English (not always a concern of linguists), the lexical base of a creole - the donor from which it has drawn the bulk of its vocabulary - and the metropolitan language with

${ }^{1}$ The now standard Haitian orthography has "Kreyòl" but given that I have referred throughout to French creoles other than Haitian Kreyòl, I prefer to attempt introducing "Kreyol" as a neologism in English for the collectivity.

${ }^{2}$ Standard definitions of creolist terminology can be found in Holm (1988, pp. 1-68) and in my Entwisted Tongues: Comparative Creole Literatures (2000, pp. 1-20). For reasons of space, I must leave aside more consideration of the "common creole culture" of the Caribbean. Much of my perspective bears implicit reference to polysystem theory; for a previous statement about this connection, please see Lang (1987). 
which it is in most contentious contact are not always the same. Sranan has an English lexical base, but Dutch is the language of state in Suriname and the one spoken most fluently by most Sranan-speakers. Likewise, Papiamentu was "seeded" by Portuguese, but Spanish early on infused it with vocabulary and speech patterns. Virtually all speakers of Papiamentu are fluent in Spanish, literate in Dutch and conversant with English.

Another alternative term for the former colonial languages is "superstrate" ("the language with those with more power," per Holm, 1988, p. 5). The problem here is that the superstrate is not necessarily that into which creoles are translated nor, to anticipate discussion below, that from which source texts translated into creoles are drawn. For example, the Curaçaoan Jozef Sickman Corsen's Papiamentu poem "Atardi" (Sunset) is a translation of a Spanish translation of Heine's poem "Ich weiß nicht was soll es bedeuten" (I know not what it ought to mean), whose first lines read, Ta pakiko mi no sa, ma esta tristu mi ta bira (Lang, 2000, p. 253). We must accordingly rule out "colonial language" as a catch-all term since the Netherlands Antilles were colonized by the Dutch, and it is English if anything which is the most frequent SL and even increasingly $\mathrm{TL}$ of translation involving Papiamentu. Colonial and post-colonial dynamics are operative in all creole contexts, but in ways which often reveal how superficially these two terms can be used. Whatever its disadvantages, then, the use of "metropolitan language" as a sort of antonym for "creole language" in this particular traductological context at least refers to the principal speech situation of creoles: they both are peripheral to the world system of languages, one in which English is ascendant, but French, Spanish, Portuguese and Dutch continue to play relatively dominant roles within certain settings.

Dutch and German offered the first systematic European interface with creoles. The history of writing in a creole begins with the Slavenbriefen or Slave Letters inscribed in Negerhollands, the Dutchbased creole of the eighteenth century Virgin Islands, which were conveyed into archives in Herrnhut, Germany by the German-speaking Moravian Brethren missionaries, who belonged to the same sect as the authors of the first grammars and dictionaries of Sranan. In 1718 the so-called Herlein phrase-book in Sranan and Dutch was published with a sample of early Sranan against Dutch (Oudy, Oeu fasje jou tem, My bon, Jou bon toe? Good day. How are you? I'm well. And you?), and in 1783 Henrik Schouten published his "Een huishoudelijke twist" (A 
Domestic Tiff), in which a Dutch-Creole couple upbraid each other in their respective languages (Voorhoeve and Lichtveld, 1975, pp. 286288). Though strictly speaking "Een huishoudelijke twist" is a bilingual dialogue rather than mere translation of Sranan into Dutch, the inclusion of Sranan and its relative intelligibility to some intended readers makes it relevant to my discussion. Early writing in creoles is in some cases transcription, but in other cases the creole emulates the metropolitan tongue, so is perhaps best understood as transposition of the norms and values of the reigning literary system into a language which lacks a coherent and systematic gamut of literary registers and styles of its own. Like some contemporary theorists of translation, I would include these modes of transposition in a general typology of translational strategy (see for example Robinson, 1997, pp. 10-11). Within this framework, almost all early writing in creole is translation in the broad sense of the word, not that there are no issues of authenticity to be raised. For example, the first Haitian poem in print, "Lisette quitté la plaine" (Lisette, leave the lowlands) was composed by a white Haitian planter, Duvivier de la Mahautière. There is no doubt that "Lisette" "translates" the form and to some extent the content of eighteenth century French lyric, and may well itself have been a creole translation of a lost ditty in French. But there is also evidence that it might have belonged to a genre of lyric known as the cocotte song (Williams, 1972, p. 29), in which case it benefits from the status of independent work, and has been a ST for the French and English translations of it now cast into scholarship. Examples like this could be multiplied for the early history of all creoles since, in the sociolinguistic nebulae in which they arise, imitation and borrowing are not easily distinguished from innovation and invention.

By far the bulk of translations of creole into metropolitan languages are embedded into scholarly and semi-scholarly works of ethnography and folklore. The mid-nineteenth century work of H.C. Focke includes his 1855 dictionary of Sranan, Neger-Engelsche Woordenboek, but his 1858 report on the music of the Surinamese slaves, the first of a long tradition of ethnographical translation of Sranan, whose summum is Melville J. and Frances S. Herskovits Suriname Folk-Lore (1936), wherein a huge selection of folktales, songs and proverbs are translated to English. Similar collections were compiled and translated from Haitian Kreyol (see relevant sections of Reinecke et al., Bibliography of Pidgin and Creole Languages, 1975), but one of the most interesting "translations" remains the verse fables of Georges Sylvain, Cric? Crac! Fables de La Fontaine racontées par 
un montagnard haitien et transcrites en vers (1901) - though it should be noted that last text is not genuine literary translation, the Kreyol original not a literary translation of La Fontaine, rather adaptation, the French en regard being intended to facilitate back translation of the Kreyol. Such a list could be composed for each of the Atlantic creoles and extended up to the present date, since the compilation of proverbs and tales is still a major genre of writing in creole, and it is only recently that these texts appear without side-by-side translation. Translation in bilingual editions is in fact a frequent format for publication in creoles, precisely by way of getting the Kreyol into the print, and encouraging its reading. Atipa, the first novel in Guyanese Kreol (Parépou, 1885), has always appeared in bilingual editions, and Lambert Félix Prudent's Anthologie de la poésie créole (1984), which gathers French-based creoles from not only the Caribbean but the Indian Ocean, is bilingual in French, as is Voorhoeve and Lichtveld's Creole Drum, Sranan-English, and Hoefnagels and Hoogenbergen's Buki di proverbionan antiano (Book of Antillean proverbs, 1985) Papiamentu-Dutch.

As one might expect, translation in these contexts is marked by foreignizing, the goal of which is to call attention to the originality of the creole itself as distinct from the TL into which it is translated, an extreme case of what Venuti, after Deleuze and Guattari, calls "minoritizing" or writing the "remainder" (1997, p. 10). The scholarly or editorial apparatus is the most visible manifestation of the intention to highlight the non-domestic provenience of the creole texts, but the choice of texts (often emphasizing the "earthy" or "soulful") as well as relative literal or sometimes word-for-word phrasing underscores the alterity of the creole, as in these riddles from the Sranan (Lang, 2000, p. 130)

Mi de tyari mi oso na tapu mi baka - Pakro (I carry my house on the top of my back - Snail).

Moro mi owru, moro mi switi; te mi dede prisiri fu mi famiri - Lepi bana (The older I am, the sweeter I am; when I die there is pleasure for my family - Ripe plantain).

Mi habi wan piti, a prani lontu nanga bom, ma no wan wiriri de fadon na ini - Ay (I have a well, planted around it are trees, but not a single leaf falls from it - Eye). 
To take another example, in Sylvain's Cric? Crac! a number of expletives remain in the Kreyol, and this tendency to leave markers of untranslated Kreyol has been adopted by many contemporary metropolitan-languages writers of creole background, producing the creolisms in French-language writers like Patrick Chamoiseau (see Hazaël-Massieux, 1988). On the other hand, while Raphaël Confiant's translation of his own Kreyol novel, Marisosé (Mamzelle Libellule, Mademoiselle Dragonfly, 1987), strives for a high and poetic literary French, as opposed to the "basilectal" Kreyol of the original ${ }^{3}$, the Haitian Frankétienne, in his translations of his own "spiralist" novel Dézafi (Les Affres d'un défi, 1975) insists on creolisms, though he had banished Gallicisms from the Kreyol original.

To generalize, translation from creole languages reflects the translator's intent to reveal and even enshrine the creole as an autonomous language. It follows that translations are often accompanied by the original, that annotations and glosses and similar paratexts find a natural place in the translation and that, stylistically, little effort is made to domesticate the text to the TLs. In this first mode of creole translation (wherein creoles serve as SLs), compensation for the "gap in the domestic reader's knowledge" (per Venuti) is explicit, even ostentatious, accentuation of creole alterity being, in most cases, the primary goal.

\section{Metropolitan to creole (creoles as TLs)}

When creoles are TLs, there are basically two alternative strategies available. In the first, what I call "adversarial" translation, the translator endeavours to show that the creole can "supersede and supplant the aesthetic exploit of the source text," thereby validating it as "a legitimate equal and peer" (Lang, 2000, p. 174). Even cursory survey of literary works in creole languages - such as one might informally experience by flipping through the pages of John Reinecke et al., Bibliography of Pidgin and Creole Languages - reveals the ubiquity of this impulse. There exist versions of Shakespeare in Sierra Leone Krio (Decker, 1988 [1965]), of Camões in Capeverdian Crioulo (see the appropriate section of Reinecke et al. 1975), and innumerable translations and adaptations of La Fontaine in French creoles (Jardel,

${ }^{3}$ Basilects in this context are the literary styles which emulate, often more accurately, reconstruct, the "deep" dialects of the creole. Discussion in Lang (2000, pp. 105-142). 
1985), the masterpiece of this subgenre remaining Sylvain's Cric? Crac!. To be sure, translated classics of world literature need not be drawn from the relevant metropolitan literature to be adversarial. There also exist a La Fontaine version in Papiamentu, an Italo Calvino, a George Bernard Shaw. Similarly, John Bunyan has entered Haitian Kreyol, though this Pilgrim's Progress is closely in spirit to biblical and catechistic translation into creoles, and hardly "adversarial" in spirit, though sharing the impulse to demonstrate both the literary resources of the creole to a nascent readership.

The restraints and specificity of biblical translation into Creoles (as discussed in Hazaël-Massieux, 1995) thus represent a second mode of creole TL translation, though its modalities are roughly the same as those affecting biblical translation as a whole. There is of course a lengthy tradition of and discussion concerning such going back to St. Jerome and Luther. In essence, the challenge to the biblical translator is to render the source text as naturally and transparently as possible, since persuasion and proselytization are the goals. This does not necessarily mean that a successful translation will not arouse the ire of some readers. Luther encountered hostility to his German translation of the Bible for not only theological but "stylistic" reasons. One of the first coherent defences of creoles as literary language, William Greenfield's 1830 Defence of the Suriname Negro-English Version of the New Testament was mustered against a fellow British missionary who had questioned the propriety of casting the Bible into a degraded tongue like the "broken English" of Suriname, that is Sranan (see Reinecke, 1987). Nonetheless, the first printed text in most creoles is usually a Bible or a catechism, and the first "literary" work in any creole is the Christmas carol translated into Negerhollands and sung on Christmas Day, 1754, on the island of St Thomas (Stein, 1982). This topic has been discussed in detail by the French creolist MarieChristine Hazaël-Massieux (1995).

Despite the significance of biblical translation in the early history of literacy in creoles, adversarial translation of the canon of world literature into creole is a more representative indication of the general strategy animating creole writers and translators. Creole literatures (as opposed to oratures) are willed into existence by highly motivated intellectuals who aim to demonstrate the maturity and the wealth of their language, much like the initiators of major European "national" literatures during the Renaissance and thereafter. One example which will serve here as a kind of paradigm, are the mid- 
twentieth century translations into Sranan of the Dutch poet Willem Kloos, often known as the "Shelley" of Holland. Kloos was a leader of the Tachtigers, the principal proponents of the late nineteenth century Romantic Revival in Dutch. In the forties and fifties, Sranan language writers aspired to forms of textual autonomy usually considered a trademark of modernism, found an excellent example in Kloos work, in no small part because the imagery of his famous sonnet could also stand as a metaphor for the fragile state of Sranan at the time: "Ik ween om bloemen in den knop gebroken" (I grieve the flower crushed before it opened). Let us compare two different translations of its first stanza into Sranan, the first by J. G. A. Koenders which appeared in his literary review 1954 Foetoe-boi ("go-for boy" or servant - (futu-boi in the present official orthography):

M'e sari foe bromki, di broko bifosi den opo.

Di lasi den prodo, bifo a komopo.

M'e sari foe lobi, dilanga no tan,

bikasi mi ati a no ben froestan.

I grieve the flower crushed before it opened Spoiled before the morning of its splendour. I grieve love which never was disclosed, And also my own heart, misunderstood.

Koenders had previously launched an attack on the stilted dialect of Sranan known as Church creole, and devised an orthography to counter the Dutch-inflected one. His crusade was many-sided, embracing social activism, didacticism, and polemic. For example, he was closely associated with a women's group, Potie hanse makandra (put hands together), wrote primers on public health, and compiled a volume of sixty songs based on hymns in Dutch and incorporating Sranan lore, Sieksie Tin Tien (Sixty Tin Tien). Still, he was a transitional figure. As Voorhoeve observes, "ironically Koenders often resorted to artificial constructions more reminiscent of ponderous written Dutch than of the natural flow of creole speech" (Voorhoeve and Lichtveld 1975, p. 136).

My flat translation of Koenders cannot pretend to recapitulate the dialogical conflict of dialect and manner this translation conveys to readers of Sranan, and I will not try to offer up a translation of a second version of those lines, that proposed by the next major figure of Sranan literature, Trefossa, a few years later. 
m'e kré foe bromki masi na ini knopo,

moesdé f'den prodo srefi den no si.

M'e kré foe lobi di no loesoe opo

èn $\mathrm{f}^{\prime}$ di nowàn kon sabi ati $\mathrm{f}^{\prime \prime} \mathrm{mi}$.

Trefossa was a pseudonym of H. F. De Ziel, librarian of the Suriname Cultural Centre and editor of late nineteenth-century Sranan texts. His choice of diction and his idealized literary Sranan was "lower" than Koender's, but in many ways more modern(ist) - an assertion which I, an utterly bookish student of the language, shall not presume to demonstrate, instead referring the reader to Voorhoeve's analysis (in Trefossa 1957, pp. 37-54).

There is, as observed, ample metaphoric justification for the attention both translator-poets devoted to this poem. Sranan itself can be seen as a crushed flower whose renascence would be a thing of beauty. Both versions cleave to the sonnet form. It is possible to interpret such mimicry as typical of slavish assimilation, but each translator is not just emulating Kloos, but trying to set the parameters of the Sranan literary system as he understood them, and both have seized upon Kloos' image of interrupted flowering to formulate a poetico-political statement.

Adversarial translation is not inherently directed against the particular author or work which is translated, rather against the reigning system of norms in terms of which literary value is presumed to be the exclusive resort of the language of the hypotext. In fact, in this second context of creole translation implicature takes a very strange twist, since adversarial translation does not work unless there is shared knowledge between the translator and the reader of the accepted high status of the source text, therefore no direct need of metaliterary compensation - which does not mean of course that the translator does not need to provide other guidelines and signposts as to the intent of his or her work. In the two above cases it could be argued that Koenders and Trefossa by their choice of literary register in Sranan, are attempting to re-shape the reader's previous interpretation of the Dutch literary system, or indeed of Dutch itself, since each in his own way is endeavouring to show that a text in Sranan is more vital and engaging than its Dutch version. Whenever a creole translator deliberately writes over a culturally consecrated hypotext the transmutation is inherently polemic. Targeting a text in the alien canon of the adjacent high culture is no neutral activity. The very choice of hypotext is telling. 


\section{Creoles to creole (creole as both SL and TL)}

It is tempting to call the third possible mode of creole translation "Borgesian" since this category is largely empty, a rarely realized potential rather than a classification of actual texts, there being few examples of translation from one creole to another, in part because of the logic underlying adversarial translation (the need to respond to and resist metropolitan literary norms and values), in part simply because very few readers of creole are aware of the variety of texts in other creoles. This is to be regretted. As long as creolophones remain ignorant that speakers of other creoles face the same dilemmas and often share similar cultural frameworks, a common source of strength and inspiration will be lost. Such similar cultural frameworks in fact would facilitate translation among them, offering a special case of implicature.

Let me adduce two examples, the first a fictional bilingual exchange of letters in Capeverdian Crioulo and Papiamentu composed by Antoine J. Maduro, a Curaçao philologist, of which I cite only the initial passages, first in Papiamentu (1987, p. 8):

Mi amigu, - Den purá mi ta skirbi e dos blanchinan di papel aki, ku mi ta mandabu den e karta aki. Talbes tin kos, palabra o moda (di papia) ku bo ta kere ta fout. Loke mi no ta duda[...]

The same text is translated en regard into Capeverdian Crioulo:

Nha amigo, - Cu préssa en scrêbé és dôs fója di papel, qui dentro d'ês karta en tâ manda nhô. Talvêz algun cúsa, palabra, ou móde nhu crê, estâ êrrado. Cuza qu'en câ tâ dubida[...]

Here is the translation:

Dear Friend, - Hastily, I have written these two pages that I am sending to you in this letter. Perhaps there are things, words or forms of speech that you will find to be in error. Of this I do not doubt...

Leaving aside the fact that the orthography Maduro utilized for both creoles is antiquated by current standards, this conflation of distant creoles serves to remind that unsuspected congruencies have been inscribed into them due to their shared status as Iberian creoles, and perhaps, as we shall see, as creole per se. Along with Holm, I do not share Maduro's belief, shared with some proponents of Papiamentu, 
that the two languages are directly connected, in the sense that Papiamentu is derived from the same branch of Afro-Portuguese or a Portuguese pidgin spoken on the slave ships ${ }^{4}$. Any student or scholar of Romance languages will, however, recognize an eerie affinity between the two extracts. As Maduro's first interlocutor implies, the untrained non-native speaker of either language would likely produce egregious errors in the counterpart creole. Yet, once a certain level of correctness in the other creole is attained, a speaker, writer or translator would find kinship and resemblance at many levels, not just the apparent cognates (from which there are indeed deviations (ta skirbi / en scrêbé; dos blanchinan di papel / dôs fója di papel ; loke mi no ta duda / cuza qu'en câ tâ dubida), but underlying cultural propinquity such that implicature and the cultural differences for which compensation is necessary would be minimal. Such affinity was precisely the point of Maduro's pamphlet, in which he hoped to bolster his argument that the deep loyalties of Papiamentu speakers belong to the shared sphere of the Atlantic creoles and the diasporan African culture they transmit.

By way of offering some concrete examples of that culture, let me examine a short poem in Sranan, translating it into English but also demonstrating how a translation into Haitian Kreyol would confront fewer difficulties. Here is the title poem of the collection Awese by Johanna Schouten-Elsenhout, the so-called Grandma Moses of Sranan literature (Schouten-Elsenhout, 1962, pp. 8-9; also in Voorhoeve and Lichtveld, 1975, pp. 220-21, whose translation in English, by Vernie A. February, I have retained).

\author{
Kabra! \\ Troki gi den afkodreyman \\ a mindri n'akapu dyari \\ pe fodu e lolo \\ nanga santi ini en ay \\ lek papawinti \\ a mindri n'aladey son. \\ Wiki den, mi kabra, \\ ini a dofokampu, \\ mindri a doti f'sranan. \\ Troki mek kromanti \\ sekete nang'a pingi fu mandron \\ a mindri den awese.
}

\footnotetext{
4 For discussion of the relationship between Papiamentu and African slave pidgins, see Holm (1989, pp.273-275; pp. 312-316). My own commentary can be found in Lang (2000, pp. 63-69).
} 
Prisi a gronmama.

Opo fey mi nengrekopu mindri a watrapan.

A ten e kot'a a greb 'olo.

\section{Forefathers!}

Invoke for the pagan priests

amidst the commons

where the voodoo snake rolls

with sand in his eyes

like a snake god

amidst the sun of every day.

Wake them, my forefathers,

in the medicine house,

in the middle of the Suriname earth.

Invoke and let Kromanti

dance the sekete on the beat of the big drum

amidst the spirits of the awese.

Honour the earth mother.

Fly up nengrekopu from the middle of the pool.

Time runs its course at the grave.

Like many creole texts translated into English, this requires considerable glossing, because its frame of reference includes motifs and categories utterly lacking in English. The implicit religious burden in "Awese" is the shared Afro-Caribbean religious world, familiar in Vaudou and thus in Haitian Kreyol ${ }^{5}$. Dofokampu (medicine house) in line 9 is akin to the Haitian Vaudou pe (temple or altar), wherein lithographs and other semblance of relevant saints are placed alongside tokens of their attributes and corresponding offerings. In Haitian Vaudou, the central post or poto mitan constitutes an axis mundi, connecting the upper and lower worlds; vèvè or signs relating to the loas are drawn in the ground or traced with grains, flour or other natural ingredients. In the above Sranan poem fodu and papawinti correspond respectively to Vaudou gods in general and in particular to the snake god, the latter melding with Haitian damballah, the rainbow-serpent ("father-spirit" in Sranan). The black-body spirit (nengrekopu, a bird: myctria americana) flies up from the middle of a pond (watrapan, water-pond). In Vaudou this passageway flows through the poto mitan, over which presides the trickster Legba, leba in the Sranan ghost or

\footnotetext{
5 English "voodoo" is so laden with negative connotation that it should be avoided at any cost, and has so been recently. Vaudou is, of course, French; vodou, the Kreyol in the standard orthography.
} 
yorka tales the Herskovits transcribed, the intermediary who arranges the arrival of the gods. But the water-mother (manman dlo) is also equated with the Sranan gronmama, "earth-mother" in the translation above. Likewise, in Suriname, kromanti are a subset of African deities whose name comes from the old slave fort on Ghanaian coast, Cormantyne, but the cool, white deities of Haitian rada are similarly associated with the West African coast, as opposed to the hot red ones of the violent petro-lemba set. The word awese itself is difficult to translate, but Ndjuka has awasa for a dance signaling the end of mourning, the gist of Schouten-Elsenhout's poem, invoking, as it does, ceremonial renewal. Her sekete or shake-dance (seki, shake) begins to the beat of the mandron or big drum (Haitian banboula) ${ }^{6}$. Surely, were there a poet-translator fluent in Haitian and knowledgeable of Sranan, some less rambling exegesis than this would be possible. Creole to creole translation would confirm the common cultural heritage of these languages despite their different lexical borrowings and origins. This project is not mine to fulfil.

\section{Conclusion}

As this brief study of the three possible translational settings for creoles shows, such translation is subject to a number of special constraints, and indeed the languages themselves are. With very rare exception, creoles are dominated languages, though domination is, it should be kept in mind, a relative notion. It follows that a considerable array of interpretative devices must compensate for the distance between the exotic creole SL and the hegemonic TL, and in fact display of these devices may be exaggerated or fetishized in order to demonstrate the uniqueness of the creole and its culture.

The second of our modes of creole translations, that in which works from hegemonic cultures are translated into dominated ones, does not conform strictly to Robinson's view of things: "a dominated culture will invariably translate far more of a hegemonic culture than the latter will of the former" $(1997$, p. 234). Although the great bulk of biblical translation provides evidence that this tendency can on occasion prevail, adversarial translation of the world canons suggests a variation on Robinson's rule, one due to the special relationship creoles

\footnotetext{
${ }^{6}$ Herskovits and Herskovits (1936) is the starting point for study of Sranan religion, but Brana-Shute (1990) surveys recent literature. A helpful description of Vaudou practice can be found in Matibag (1996), pp. 184-225.
} 
have with hegemonic languages, in particular those languages which are "metropolitan" to them. Here the dominated culture fights back and selects the "best" within its enemy's arsenal with which to test itself. At the same time, there is quantitatively much more translation into creole than might normally be the case, since almost all readers of creoles are bilingual in the relevant metropolitan language and have chosen literacy in creole for personal, political, or polemic reasons. Only when (or if) the market for reading in creoles grows to the point that translations from English, French, etc., become lucrative will there be a massive influx of translated material into creoles, one which introduces more than specially targeted and prestigious foreign texts.

Although creoles are to some extent "hyper-dominated" languages, we should not presume that the dialectic of dominationhegemony does not enter at all into the third mode of creole translation. Some creoles are in fact "more equal" than others. In cases where a given creole has social and political power over another, the principles sketched immediately above would tend to prevail. For example, the creole Saramaccan is spoken in the hinterland of Suriname, a country where coastal Sranan partakes of considerable albeit relative prestige, despite its own domination by Dutch. Haitian Kreyol tends to impose itself as norm over the other French Antillean creoles, given the mass of its unilingual speakers. The struggle for predominance among dialects of the same creoles also replicates this dialectic of struggle. During the 1970s and 1980s, the southern dialect of Capeverdian Crioulo, based on the capital city of Praia, set the norms for that literary system, speakers of the Aruban dialect of Papiamentu continue to resist the imposition of Curaçaoan based Papiamentu, including its orthography. To some extent, these conflicts and struggles could be considered "translational".

In other words, not only can the particularity of creole translation shed light upon general problems of translation, as I hope it has here, but translation studies offers a useful tool to explore the nature of creoles.

University of Alberta 


\section{References}

BRANA-SHUTE, Gary, ed. (1990). Resistance and Rebellion in Suriname: Old and New. Williamsburg, VA, Department of Anthropology, College of William and Mary.

CONFIANT, Raphaël (1994). Mamzelle Libellule, trans. of Marisosé by author. Paris, Le Serpent à Plumes.

- (1987). Marisosé. Saint-Estève, Presses universitaires Créoles.

DECKER, Thomas (1988 [1965]). Juliohs Siza, eds. Neville Shrimpton and Njie Sulayman. Umeå, Sweden, Umeå University.

FOCKE, H.C. (1855). Neger-Engelsch Woordenboek. Leiden, P.H. van den Heuvell.

- (1858). « De Surinaamsche negermuzijk » West-Indië, $\mathrm{n}^{0} 2, \mathrm{pp} .93-$ 107.

FRANKÉTIENNE (1979). Les Affres d'un défi. Port-au-Prince, Imprimerie Henri Deschamps.

- (1975). Dézafi. Port-au-Prince, Éditions Fardin.

HAZAËL-MASSIEUX, Marie-Christine (1995). " À Propos de la traduction de la Bible en créole ", Études créoles, vol. 18, nº 1, pp. 3973.

- (1988). « À propos de Chronique de sept misères: Une littérature en français régional pour les Antilles ", Études créoles, vol. 11, $\mathrm{n}^{0} 1, \mathrm{pp}$. 118-131.

HERSKOVITS, Melville J. and Frances S. HERSKOVITS (1969 [1934]). Suriname Folk-Lore. New York, AMS Press.

HOEFNAGELS, Peter and Shon W. HOOGENBERGEN, eds. (1985). Buki di Proverbionan Antiano: Antilliaans Spreekwoordenboek. Kòrsou, De Curaçaosche Courant.

HOLM, John (1988-1989). Pidgins and Creoles, 2 vols. Cambridge, Cambridge University Press. 
JARDEL, Jean-Pierre (1985). « Des quelques emprunts et analogies dans les fables créoles inspirées de La Fontaine. Contribution à l'étude des parlers créoles du XIX ${ }^{\mathrm{e}}$ siècle ", Études créoles, vol. 8, $\mathrm{n}^{\circ} 1 / 2, \mathrm{pp}$. 213-225.

KOENDERS, J. A.-G (1944). Sieksie Tien Tien: Moi en bekente Siengi. Paramaribo, Drukkerij Eben-Haëzer.

LANG, George (2000). Entwisted Tongues: Comparative Creole Literatures. Amsterdam, Rodopi.

- (1987). "Periphery as Paradigm: Creole Literatures and the Polysystem". Poetics Today, vol. 8, n⿳3 3/4, pp. 529-537.

MATIBAG, Eugenio (1996). Afro-Cuban Religious Experience. Gainesville, University Press of Florida.

MADURO, Antoine J. (1987). Kaoberdiano i Papiamentu. Kòrsou, Maduro \& Curiel's Bank, N.V.

STEIN, Peter (1982) «Die Kreolischen Lieder des Weihnachtsgottesdienstes vom 25. Dezember 1754 in St Thomas», Unitas Fratrum, vol. 12, pp. 106-112.

PARÉPOU, Alfred (1987 [1885]). Atipa, ed. and trans. by Marguerite Fauquenoy, Paris, L'Harmattan.

PRUDENT, Lambert Félix (1984). Anthologie de la nouvelle poésie créole. Paris, Éditions caribéennes.

REINECKE, John E. (1987). «William Greenfield, a Neglected Pioneer Creolist», Pidgin and Creole Languages: Essays in Memory of John E. Reinecke, ed. Glenn G. Gilbert. Honolulu, University of Hawaii Press, pp. 23-34.

REINECKE, John E., Stanley M. TSUZAKI, David DECAMP, Ian F. HANCOCK, and Richard E. WOOD, eds. (1975). A Bibliography of Pidgin and Creole Languages. Honolulu, University of Hawaii Press.

ROBINSON, Douglas (1997). Becoming a Translator. London and New York, Routledge. 
SCHOUTEN-ELSENHOUT, Johanna (1965). Awese. Paramaribo.

SYLVAIN, Georges (1929 [1901]). Cric? Crac! Fables de La Fontaine racontées par un montagnard haïtien et transcrites en vers créoles. Port-au-Prince, Éditions Fardin.

TREFOSSA [pseud. of Henri Frans de Ziel] (1977). Ala poema foe Trefossa comp. Jan Voorhoeve. Paramaribo, Bureau Volkectuur.

- (1957). Trotji: Puëma, met een stilistische Studioe over het gedicht «Kopenhagen». Amsterdam, Noord-Hollandsche Uitgevers Masstschappij.

VENUTI, Lawrence (1997). The Scandals of Translation. London and New York, Routledge.

VOORHOEVE, Jan and Ursy M. LICHTVELD, eds. (1975). Creole Drum: An Anthology of Creole Literature in Suriname. New Haven and London, Yale University Press.

WILLIAMS, Perry Arthur (1972). La Fontaine in Haitian Creole: A Study of "Cric? Crac!» by Georges Sylvain. Fordham University, Dissertation.

ABSTRACT : Translation from, to and within the Atlantic Creoles - Translation involving creole languages suffers the general disadvantage of writing in creoles: low levels of literacy, the lack of standard orthographies, the overwhelming economic and cultural power of the metropolitan languages with which they compete. The pitfalls attendant to translation in any language are thus aggravated when translating to and from creoles, and these adverse sociolinguistic conditions affect the role of creoles as source and as target languages differently. Another possibility is of course that creoles serve as both $\mathrm{SL}$ and TL, and that translation be between or among creoles - a rather rare case. These three eventualities raise several issues of translation theory, in particular the role of shared implicature in languages whose cultures are related (Venuti, 1997). At the same time, certain concepts of translation theory explored recently by Robinson (1997) and others, can shed light upon the particular social and political problems faced by these languages. 
RÉSUMÉ : Traduction et créoles atlantiques - La traduction des langues créoles est sujette aux désavantages que ces langues ellesmêmes rencontrent : de bas niveaux d'alphabétisation, le manque d'orthographes établies, les effets néfastes du pouvoir que les langues " métropolitaines » exercent sur elles. Les difficultés générales de la traduction littéraire se trouvent donc aggravées quand il s'agit de la traduction soit d'une langue créole, soit vers une langue créole, soit entre des langues créoles, et les conditions sociologiques de base affectent l'entreprise de traduction différemment si le créole est source ou cible ou encore si des créoles servent les deux fonctions à la fois bien que ce dernier cas soit effectivement rare. Cette étude de ces trois modes de traduction créole reposera sur plusieurs points reconnus de la traductologie, en particulier le rôle que joue l'implicature dans la traduction des langues dont les cultures sont apparentées (Venuti, 1997). Inversement, celui-là et d'autres concepts traductologiques exposés par Robinson (1997) pourraient s'avérer utiles aux créolistes qui se penchent sur les problèmes sociaux et politiques qui frappent ces langues.

Key words: creoles, minority languages, "adversarial translation", polysystem theory, post-colonialism.

Mots-clés : les créoles, les langues marginales, la " traduction antagoniste ", la théorie du polysystème, le post-colonialisme.

George Lang: Modern Languages and Cultural Studies, University of Alberta, Edmonton, Alberta, Canada T6G 2E6

E-mail : George.Lang@ualberta.ca 